\title{
Content of bioactive compounds in the peach kernels and their antioxidant, anti-hyperglycemic, anti-aging properties
}

\author{
Paulina Nowicka ${ }^{1} \cdot$ Aneta Wojdyło ${ }^{1}$
}

Received: 13 September 2018 / Revised: 24 November 2018 / Accepted: 1 December 2018 / Published online: 18 December 2018

(c) The Author(s) 2018

\begin{abstract}
In this study, the content of bioactive compounds (polyphenols and tetraterpenoids), antioxidative activity, and inhibitory activities toward $\alpha$-amylase, $\alpha$-glucosidase, cholinesterase of different cultivars of peach kernels were measured. Such results have not been published so far. It has been shown that peach kernels were characterized by a similar profile of bioactive compounds as the peach fruit, however, the content of some of these compounds was completely different. The total content of polyphenols ranged from 12.7 to $3.8 \mathrm{~g} / 100 \mathrm{~g} \mathrm{dm}$, the carotenoids contains were from 101.7 to $0.0 \mathrm{mg} / 100 \mathrm{~g} \mathrm{dm}$ and the amount of cyanogenic glycoside ranged from 245.7 to $17.4 \mathrm{mg} / 100 \mathrm{~g} \mathrm{dm}$. The peach kernels were also characterized by high antioxidative potential and the ability to inhibit enzymes linked to obesity, type 2 diabetes and Alzheimer's disease. The study showed that the health-promoting properties of peach kernels are stimulated by polymeric procyanidins, hydroxycinnamic acids, carotenoids and cyanogenic glycosides. Generally, it was confirmed that peach kernels could be a valuable source of polyphenols used by the pharmaceutical industry for the production of dietary supplements to support the prevention of chronic non-communicable diseases.
\end{abstract}

Keywords Peach kernels · Polyphenolic compounds · Carotenoids $\cdot \alpha$-Amylase inhibitory activity $\cdot \alpha$-Glucosidase inhibitory activity $\cdot$ Cholinesterase-inhibiting activities

\section{Introduction}

Prunus persica L. Batsch belongs to the Rosaceae family and is an initial species for many cultivars commonly grown worldwide. P. persica fruit is one of the most popular stone fruits suitable for direct consumption and an interesting material for the food industry. According to statistical data published by the Food and Agriculture Organization (FAO), the global production of peach fruits in 2016 was at 17.8 million tons, about $40 \%$ of which were produced in the European Union. The main European producers of peaches are Spain, Italy, Greece and France. In Poland, according to the Statistics Poland [1], peach production in 2016 amounted around 20911 tons. Peach fruit is suitable for direct consumption and is an interesting material for processing. The main directions of using these fruits are focused

Paulina Nowicka

paulina.nowicka@upwr.edu.pl

1 Department of Fruit, Vegetable and Plant Nutraceuticals Technology, Wrocław University of Environmental and Life Sciences, 37 Chełmońskiego Street, 51-630 Wroclaw, Poland on manufacturing very sweet products such as: jams, jellies, purees, and fruit mousse added to yogurts or as an ingredient to smoothie-type products. During industrial processing of peaches, the kernels are usually removed and become a by-product [2]. Considering that the peach kernels constitute from 5 to $10 \%$ of the total fruit weight, depending on the variety, ten thousands of tons of waste are generated annually, which are currently underexploited. Meanwhile, according to the respective regulations, they can be freely transferred or sold to a person or organizational unit for their own needs including for further processing [2].

Currently, the kernels of stone fruits are used occasionally as an ecological biofuel with a high calorific value, which combustion emits $30 \%$ less $\mathrm{CO}_{2}$ into the atmosphere, as well as from 6 to 15 times less sulfur oxides than burning brown or stony coal. However, due to the limited availability of the raw material and the necessity of introducing structural changes to adapt the stone burning furnaces, this solution is still not widely used [3]. Another way to manage peach kernels is to use them as a valuable lignin-cellulose raw material for the production of activated carbon, in pulp and paper production, for increasing 
forage crops digestibility and, more recently, for the production of biofuels [4]. Activated charcoal, obtained from kernels of stone fruits, is characterized by properties enabling its use in the food industry to remove ochratoxin A in the production of red wine, while preserving polyphenolic compounds in the product. Fruit stones, are also used in the cosmetic industry separated from sour cherries, sweet cherries or apricots, and then crumbled shells are added to epidermal cosmetics due to good friction properties [2]. Oil pressed from the kernels of fruits (rich in unsaturated fatty acids and tocopherols) is also highly valued in the cosmetics industry owing to its anti-wrinkle properties and skin protection against UV radiation.

With the increase of knowledge about the ingredients contained in kernels of stone fruit and their health-promoting potential, a great interest is aroused by the possibility of their use for human consumption, especially to enrich man's diet with compounds beneficial in the prevention of chronic diseases [5]. Although the process of separating the kernels from the peach stones is not easy-due to the hardness of the shells, the growing interest of this waste material encourages scientists to optimization of this process. In the literature we can find few processing techniques of peach stones [6] including devices to shell cracking and seed taking for peach kernels [7]. Therefore now it is easier to obtain or buy the peach kernels.

Therapeutic properties of kernels separated from peach fruits have been exploited for years, especially in the folk medicine in China (the country of origin of this fruit material). They have been reported to exhibit antimycotic and bactericidal properties [8]. However, these properties were attributed to them on the basis of certain observations, and not on science-based evidence. The kernels of most native species have so far not been examined in detail in terms of the composition of bioactive compounds and healthpromoting properties. However, it can be hypothesized that the above morphological part of peach fruit is a rich source of bioactive compounds and, therefore, capable of inducing some pro-health effects. In-depth knowledge and analysis of the composition and the bioactive potential of kernels can increase the interest in these morphological parts, so far perceived as worthless and unnecessary in human nutrition, and thus contribute to their future use, both in industry, pharmacy and also in nutrition by significantly increasing the nutritional value of an everyday diet.

Therefore, the main aim of this study was the quantitative and qualitative determination of bioactive compounds of peach kernels of 20 different cultivars and their healthpromoting properties. This goal was achieved by the analysis of the chemical composition of kernels isolated from Prunus persica, with a particular focus on their bioactive components, i.e., carotenoids, phenolic compounds and cyanogenic glycosides, and also by in vitro determination of their health-promoting properties, including their antioxidative, antidiabetic, anti-obesity, and anti-aging activities.

\section{Materials and methods}

\section{Chemicals and reagents}

All reagents to determine of pro-health properties by in vitro (acetylthiocholine iodide, acetylcholinesterase, butyrylcholinesterase, butyrylcholine chloride, DMSO, starch, $\alpha$-amylase, $\alpha$-glucosidase, $p$-nitrophenyl- $\alpha$-Dglucopyranoside, tacrine, acarbose) were purchased from Sigma-Aldrich (Steinheim, Germany). Quercetin-3-O-glucoside, keampferol-7- $O$-neohhesperiodise, hesperidin-7-rutinoside, luteolin-7-glucoside and isorhamnetin-3-O-rutinoside, (-)-epicatechin, procyanidins A2 and B2, $\beta$-carotene, $\beta$-cryptoxanthin, zeaxanthin, amygdalin and prunasin were purchased from extrasynthese (Lyon Nord, France). Chlorogenic, neochlorogenic acids were supplied by TRANS MIT GmbH (Giessen, Germany). Trolox (6-hydroxy-2,5,7,8-tetramethylchroman-2-carboxylic acid), 2,2'-azinobis-(3-ethylbenzthiazoline-6-sulfonic acid) (ABTS), acetic acid, $\mathrm{FeCl}_{3}$, phloroglucinol, ascorbic acid, TPTZ (2,4,6-tripyridyl-1,3,5triazine), acetonitrile, and methanol were purchased from Sigma-Aldrich (Steinheim, Germany).

\section{Materials}

Kernels separated from fruits of 20 peach cultivars ('Harbinger', 'Kijowska wczesna', 'Spring time', 'Beta', 'Maycresh', 'Harrow diamond', 'Dixired', 'Candor', 'Harnaś', 'Sweet haven', 'WB 258', 'Early Redhaven', 'SB6A-35', 'Jerseyland', 'BL6', 'Red Cup', 'Royalvee', 'Flamin Fury', 'Harrow Beauty', 'Madison') were used in this study. The fruit were harvested at the Research Station for Cultivar Testing in Zybiszów near Wrocław (513ㄱ'51.11"N, 16 $\left.54^{\circ} 43.56^{\prime \prime} \mathrm{E}\right)$ at "ready-to-eat" ripening stage during the 2016 season. Immediately after harvest, the stones were separated from the fruit. After that all stones were crushed using a laboratory hydraulic press. The shells were then separated by hand, and the remaining kernels were lyophilized and then ground in an electric mill and packaged in a vacuum. Until the tests, the dried, crushed kernels were stored at $-20^{\circ} \mathrm{C}$.

\section{Identification and determination of polyphenols, including with procyanidins}

The identification (LC-MS/QTof) and quantification (UPLC/ PDA/FL) analysis of polyphenolic compounds were performed as described previously by Wojdyło, Nowicka, Laskowski, Oszmiański [9]. To the determination of phenolic compounds were used the retention times and spectra 
which were compared to those of the authentic standards or/and literature data. The quantification of polyphenols was performed by external calibration curves, using reference compounds selected based on the principle of structure related target analyte/standard (functional group or chemical structure).

The analysis of polymeric procyanidins by phloroglucinol method was performed according to the protocol described previously by Kennedy and Jones [10]. The results were expressed as $\mathrm{mg} / 100 \mathrm{~g}$ of dried kernels.

\section{Identification and determination of tetraterpenoids}

The extraction and determination of tetraterpenoids were performed according to a protocol described by KolniakOstek [11]. To the determination of carotenoids were used the retention times and spectra which were compared to those of the authentic standards or/and literature data. In turn, the quantification was performed by calibration curves of selected compounds. The results were expressed as $\mathrm{mg} / 100 \mathrm{~g}$ of dried kernels.

\section{Identification and determination of cyanogenic glycosides}

For the extraction and then identification and determination of cyanogenic glycosides the powder kernels $(0.20 \mathrm{~g})$ were shaken with $5 \mathrm{~mL}$ of methanol and sonicated for $15 \mathrm{~min}$ to improve the extraction process. Samples prepared in this way, were stored for $24 \mathrm{~h}$ at $4{ }^{\circ} \mathrm{C}$ and after this time, sonicated again $(15 \mathrm{~min})$. The samples were then heated in a water bath at $70{ }^{\circ} \mathrm{C}$ for $30 \mathrm{~min}$. After the extraction, the samples were centrifuged at $19,000 \mathrm{~g}$ for $10 \mathrm{~min}$, and the supernatant was recovered. Supernatant was evaporated to dryness and then to the pellet was added $5 \mathrm{ml}$ of diethyl ether to dissolve the fatty compounds and precipitate the cyanogenic glycosides. Diethyl ether solution was evaporated and the isolated compounds were dissolved using $4 \mathrm{ml}$ of methanol, filtered through hydrophilic PTFE $0.20 \mu \mathrm{m}$ membrane and used for analysis. The analysis of cyanogenic glycosides by LC-MS/QTof and UPLC/PDA methods were performed according to the protocol described previously by Wojdyło et al. [9] for polyphenols. The results were expressed as $\mathrm{mg} / 100 \mathrm{~g}$ of dried kernels.

\section{a-Amylase, a-glucosidase and pancreatic lipase inhibition assays}

The $\alpha$-amylase and $\alpha$-glucosidase inhibitory effects of the peach kernels were assayed according to the procedure described previously by Nowicka, Wojdyło, Samoticha [12] while the inhibition of lipase activity was determined according to Podsędek et al. [13], respectively. The results were expressed as $\mathrm{IC}_{50}$ value.

\section{Determination of antioxidant activity by ORAC, and ABTS methods}

The solvent for the analysis of antioxidant activity in peach kernels was prepared as described previously by Wojdyło et al. [9]. The oxygen radical absorbance capacity (ORAC), and 2,2'-azino-bis(3-ethylbenzothiazoline-6-sulphonic acid) (ABTS) assays were prepared as previously described by Ou et al. [14] and Re et al. [15], respectively. The antioxidant activity was expressed as mmol Trolox/100 $\mathrm{g}$ of peach kernels.

\section{Determination of inhibitory activities toward acetylcholinesterase and butyrylcholinesterase}

Acetycholinesterase (AChE) and butyrylcholinesterase (BChE) activity was determined by the Ellman method with slight modifications presented by Jin et al. [16]. The enzyme inhibition assays were expressed as $\mathrm{IC}_{50}$ value.

\section{Statistical analysis}

Statistical analysis was conducted using Statistica version 12.50 (StatSoft, Krakow, Poland). Significant differences $(p \leq 0.05)$ between means were evaluated by one-way ANOVA and Duncan's multiple range test. All data included in this study are presented as the mean value \pm standard deviation and were performed at least three times.

\section{Results and discussion}

\section{Identification of phenolic compounds in kernels of peach stones}

Table 1 shows the data after liquid chromatography photodiode array quadrupole time-of flight mass spectrometry (LC-MS/QTof) analysis. The LC-MS analysis of 20 different cultivars of peach kernels allowed for the identification of 18 phenolic compounds. These can be classified into three groups: flavonols and flavons, flavan-3-ols (monomer, dimers, and polymeric procyanidins), and phenolic acids (hydroxycinnamic and hydroxybenzonic acids).

The first fraction contained in peach kernels were flavan3 -ols identified as six compounds of this group: $(+)$-catechin and (-)-epicatechin both with $[\mathrm{M}-\mathrm{H}]^{-}$at $m / z=289$, and also derivatives of epicatechin such as: (-)-epicatechin gallate $\left([\mathrm{M}-\mathrm{H}]^{-}\right.$at $\mathrm{m} / \mathrm{z}=441$ and $\mathrm{MS} / \mathrm{MS}$ fragment at $\mathrm{m} / \mathrm{z}=289$ ), a compound commonly found in tea leaves [17]. In addition, 
Table 1 Bioactive compounds identified by LC-MS in kernels separated from peach fruit

\begin{tabular}{|c|c|c|c|c|}
\hline \multirow[t]{2}{*}{ Compound } & \multirow[t]{2}{*}{$t_{\mathrm{R}}(\min )$} & \multirow[t]{2}{*}{$\lambda_{\max }(\mathrm{nm})$} & \multicolumn{2}{|c|}{$[\mathrm{M}-\mathrm{H}]^{-}(\mathrm{m} / \mathrm{z})^{\mathrm{a}}$} \\
\hline & & & MS & MS/MS \\
\hline \multicolumn{5}{|l|}{ Polyphenols } \\
\hline Neochlorogenic acid & 3.31 & 323 & 353.086 & 191.054 \\
\hline Procyanidin B1 & 3.86 & 278 & 577.138 & 289.069 \\
\hline 3-O-p-Coumaroyloquinic acid & 4.00 & 323 & 337.091 & $191.056 / 183.012$ \\
\hline$(+)$-Catechin & 4.05 & 280 & 289.069 & \\
\hline Chlorogenic acid & 4.26 & 324 & 353.086 & $707.183 / 191.054$ \\
\hline Procyanidin B2 & 5.26 & 278 & 577.138 & 289.069 \\
\hline cis-5-p-Coumaroyloquinic acid & 5.33 & 324 & 337.091 & $173.096 / 163.045$ \\
\hline (-)-Epicatechin & 5.45 & 278 & 289.069 & \\
\hline 2-O-Caffeoyl-L-malate & 5.68 & 325 & 295.047 & 177.020 \\
\hline Ellagic acid & 6.51 & 364 & 301.999 & \\
\hline Quercetin-3-O-glucoside & 6.96 & 351 & 463.091 & 301.029 \\
\hline Luteolin-7-glucoside & 7.29 & 360 & 895.281 & $447.037 / 285.082$ \\
\hline (-)-Epicatechin gallate & 7.51 & 280 & 441.166 & $137.006 / 289.069$ \\
\hline Isorhamnetin-3-O-glucoside & 7.59 & 352 & 477.385 & 315.149 \\
\hline Keampferol-3-O-glucoside & 7.87 & 347 & 447.037 & 285.082 \\
\hline Keampferol-7-neohesperidoside & 8.55 & 351 & 593.011 & 285.082 \\
\hline Hesperidin-7-rutinoside & 8.92 & 360 & 609.211 & 301.029 \\
\hline Procyanidin A2 & 8.16 & 280 & 577.138 & 289.069 \\
\hline \multicolumn{5}{|l|}{ Tetraterpenoids } \\
\hline Lutein & 5.08 & 440 & $568.428^{+}$ & 551.427 \\
\hline Zeaxanthin & 5.15 & 451 & $569.016^{+}$ & \\
\hline$\beta$-Cryptoxanthin & 7.41 & 452 & $553.062^{+}$ & \\
\hline$\beta$-Carotene & 8.72 & 452 & $537.025^{+}$ & 445.105 \\
\hline$\beta$-Cryptoxanthin-myristate & 12.65 & 450 & $763.102^{+}$ & 535.011 \\
\hline$\beta$-Cryptoxanthin-palmitate & 12.85 & 450 & $791.216^{+}$ & 535.011 \\
\hline
\end{tabular}

${ }^{\mathrm{a}}[\mathrm{M}+\mathrm{H}]+(\mathrm{m} / \mathrm{z})$ for anthocyanins were obtained in the positive ion mode the kernels were found to contain procyanidin dimers of the B- and A-types with $\mathrm{m} / \mathrm{z}=577$, including: procyanidin B1 $\left(t_{\mathrm{R}}=3.86\right)$, procyanidin $\mathrm{B} 2\left(t_{\mathrm{R}}=5.26\right)$ and procyanidin $\mathrm{A} 2$ $\left(t_{\mathrm{R}}=8.16\right)$, which were identified compared to standards. Mokrani et al. [18] showed procyanidins to be the main phenolic compounds of peach fruits, in turn Tomás-Barberán et al. [19] reported in peaches the presence of many polymeric procyanidins both as a dimers and trimers.

Hydroxycinnamic acids were represented by five compounds. The main compounds of this group were identified as caffeoylquinic derivatives, especially as chlorogenic acid with $[\mathrm{M}-\mathrm{H}]^{-}$at $\mathrm{m} / \mathrm{z}=353$. In addition, one more derivative of caffeoylquinic acid was detected and identified as neochlorogenic acid $\left([\mathrm{M}-\mathrm{H}]^{-}\right.$at $\left.\mathrm{m} / \mathrm{z}=353\right)$. Also two derivatives of coumaroylquinic acid were determined and identified as: 3-O-p-coumaroyluinic acid and $c i s-5-p$-coumaroylquinic acid $\left([\mathrm{M}-\mathrm{H}]^{-}\right.$at $\mathrm{m} / \mathrm{z}=337$ and $\mathrm{MS} / \mathrm{MS}$ fragment at $\mathrm{m} / \mathrm{z}=191$, respectively), but with different retention times of 4.00 and 5.33, respectively. The fifth compound was 2- $O$-caffeoyl-L-malate $\left([\mathrm{M}-\mathrm{H}]^{-}\right.$at $\left.\mathrm{m} / \mathrm{z}=295\right)$ phenylpropanoid $o$-diphenol phaselic acid, a common plant metabolite present in various plants including red clover, subclover, radish, different flowers and leaves. Many authors confirm the content of caffeoylquinic acid derivatives in peach fruits, pointing at the same time, chlorogenic acid to be the major compound $[18,19]$. However, the coumaroylquinic acid derivatives and 2-O-caffeoyl-L-malate have not been detected so far in fruits of this species.

In addition, one hydroxybenzonic acid was detected in kernels of peach ellagic acid. It is dilactone of hexahydroxydiphenic acid with $[\mathrm{M}-\mathrm{H}]^{-}$at $\mathrm{m} / \mathrm{z}=301$. This polyphenolic compound may be found in numerous fruit containing seeds including raspberries, strawberries, cranberries or pomegranates [20,21].

Flavonols and flavons were represented by six peaks, but they did not appear in all analyzed cultivars of kernels. They were qualified as five types of flavonol derivatives: quercetin (with a fragment at $\mathrm{m} / \mathrm{z}=301$ ), luteolin (with a fragment at $\mathrm{m} / \mathrm{z}=285$ ), isorhamnetin (with a fragment at $\mathrm{m} / \mathrm{z}=315$ ), kaempferol (with a fragment at $\mathrm{m} / \mathrm{z}=285$ ), and hesperidin (with a fragment at $\mathrm{m} / \mathrm{z}=301$ ). The identification of sugars was based on the characteristic loss of a fragment with 
$\mathrm{m} / \mathrm{z}=308$ (rhamnoglucosides), as well as the characteristic loss of a fragment with $\mathrm{m} / \mathrm{z}=162$ (glucosides). Most of the determined compounds were identified by other authors also in peach fruits $[12,18,19]$, but luteolin-7-glucoside and hesperidin-7-rutinoside were not detected previously in fruit peach extracts. The first of them can be found in artichoke, edible flowers and leaves, in turn hesperidin-7-rutinoside is commonly determined in citrus fruit [22].

The composition of polyphenolic compounds identified in the peach kernels in this study agrees, to some extent, with the identification presented by Senica et al. [23] in studies carried out on kernels of sweet cherries and apricots. They showed the presence of phenolic acids: chlorogenic, neochlorogenic, feruloylquinic, dicaffeoylquinic acids and ellagic acid derivatives, as well as (+)-catechin, (-)-epicatechin and flavonols quercetin, keampferol, naringenin and apigenin derivatives. In turn, Bak et al. [7] identified 13 different polyphenolic compounds in sour cherry kernels, including dimers and trimers of flavan-3-ols; quercetin derivatives, caffeic acid derivatives as well as anthocyanins, i.e. cyanidin and peonidin derivatives.

\section{Content of phenolic compounds in kernels of peach stones}

The average total polyphenols content of 20 analyzed peach kernels was $8.11 \mathrm{~g} / 100 \mathrm{~g} \mathrm{dm}$, while the polymeric procyanidins accounted for more than $90 \%$ of phenolic compounds (Table 2). The highest contents of polyphenols were determined in the kernels isolated from the early-maturing cultivars of peach: 'Spring time' $12.70 \mathrm{~g}$, 'Kijowska wczesna' $12.40 \mathrm{~g}$ per $100 \mathrm{~g} \mathrm{dm}$, while the lowest ones in kernels from the late-maturing cultivars,: 'Flamin fury' $3.96 \mathrm{~g}$, 'Harrow beauty' $3.63 \mathrm{~g}$, and 'Madison' $3.76 \mathrm{~g}$ in $100 \mathrm{~g} \mathrm{dm}$. Generally, the analyzed cultivars of kernels differed significantly in the content of phenolic compounds. The same trend was found in peach fruit extracts. This difference depends on both the cultivar, geographical origin, climate factors and environmental conditions [24].

The predominating compounds of polyphenols in peach kernels were polymeric procyanidins (flavan-3-ols group). Their content ranged from $10.98 \mathrm{~g}$ in 'Kijowska wczesna' to $2.86 \mathrm{~g}$ in 'Madison' per $100 \mathrm{~g} \mathrm{dm}$. The high content of polymerized compounds in peach kernels is also confirmed by the typical bitter and tart flavor of their kernels, which is an unacceptable sensory attribute for people and animals. In addition, it was observed, that kernels isolated from the early-maturing cultivars had a higher content of polymeric procyanidins, than the later-maturing ones. The difference, as in the case of fruit, could result from exposure to light and maturation process. Renard et al. [25] showed that a highly polymerized fraction disappeared during the maturation and also that the contents of flavonols and procyanidins in fruit appeared to run anti-parallel to the growth curve.

In addition to polymeric procyanidins also monomers and dimers of flavan-3-ols were detected in the analyzed kernels. Kernels of all studied cultivars were found to contain (+)-catechin, which concentration ranged from $49.49 \mathrm{mg} / 100 \mathrm{~g} \mathrm{dm}$ in 'Spring time' to $250.79 \mathrm{mg} / 100 \mathrm{~g}$ $\mathrm{dm}$ in 'Sweet haven', and also (-)-epicatechin gallate (with average content in peach kernels $421.64 \mathrm{mg} / 100 \mathrm{~g} \mathrm{dm}$ ). The higher content of this compound was detected in the latematuring cultivars, than in the early cultivars. In most of the tested peach kernels, there were detected dimers of flavan3-ols: procyanidin B1 (except 'Harrow beauty' and 'Madison') and procyanidin B2 (except 'WB 258', 'SB6A-35', 'Royalvee'). Their average content in the analyzed kernels was 150.65 and $28.12 \mathrm{mg} / 100 \mathrm{~g} \mathrm{dm}$, respectively. The most diverse, in relation to the content of this group, was procyanidin A2, which was not identified in the majority of tested cultivars, while in the 'Harbringer' kernel its content was at $324.31 \mathrm{mg} / 100 \mathrm{~g} \mathrm{dm}$, constituting $52 \%$ of total flavan-3-ols (monomers and dimers). Also (-)-epicatechin was detected in only four kernels and its content ranged from 18.62 to $33.74 \mathrm{mg} / 100 \mathrm{~g} \mathrm{dm}$.

None of the above flavan-3-ols was identified by Bak et al. [7], who studied polyphenolic compounds in sour cherry kernels. In turn, Senica et al. [23] found the presence of procyanidin dimers in sweet cherry kernels in the average amount of $6.72 \mathrm{mg} / 100 \mathrm{~g}$, and also in apricot kernels. Besides dimers $(5.87 \mathrm{mg} / 100 \mathrm{~g})$, they determined also $(+)$-catechin and (-)-epicatechin in the amount of 3.91 and $2.81 \mathrm{mg} / 100 \mathrm{~g}$ on average, respectively.

Also phenolic acids were detected in the analyzed peach kernels. The major compound among the hydroxycinnamic acids was chlorogenic acid, not identified in the 'Rayalvee', while in the other tested cultivars its content ranged from $72.92 \mathrm{mg}$ in 'Harrow beauty' to $1727.05 \mathrm{mg}$ in the 'Spring time' in $100 \mathrm{~g} \mathrm{dm}$. Also a high content of neochlorogenic acid was determined in peach kernels. It was detected in all analyzed kernels with the average content of $130.07 \mathrm{mg} / 100 \mathrm{~g} \mathrm{dm}$. Many authors confirm the high content of hydroxycinnamic acids in peach fruits, pointing also that the main compounds in this group are chlorogenic and neochlorogenic acids [18, 19]. In turn, Senica et al. [23] showed that chlorogenic acid was found in the largest quantities also in kernels of other fruit from the same family: apricots and sweet cherries ( 1.8 and $1.5 \mathrm{mg} / 100 \mathrm{~g}$, respectively).

In the analyzed peach kernels were detected also others phenolic acids (Table 2), namely: 2-O-caffeoylL-malate (from 17.10 to $130.52 \mathrm{mg} / 100 \mathrm{~g} \mathrm{dm}$ depending on the cultivar, except three late-maturing cultivars); 3- $O$ - $p$-coumaroyloquinic acid (from 9.60 to $70.22 \mathrm{mg} / 100 \mathrm{~g} \mathrm{dm}$ depending on the cultivar, except six 


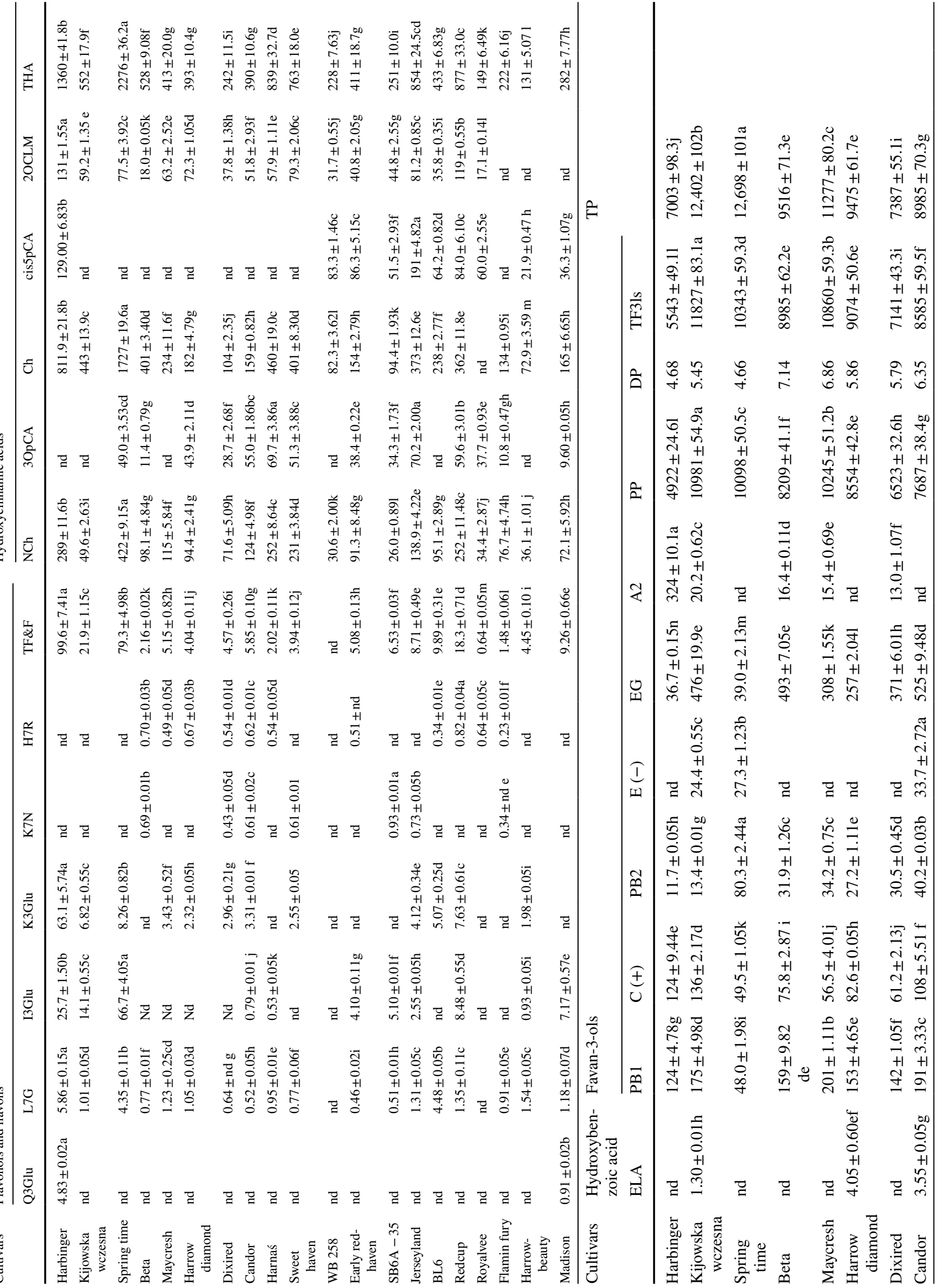




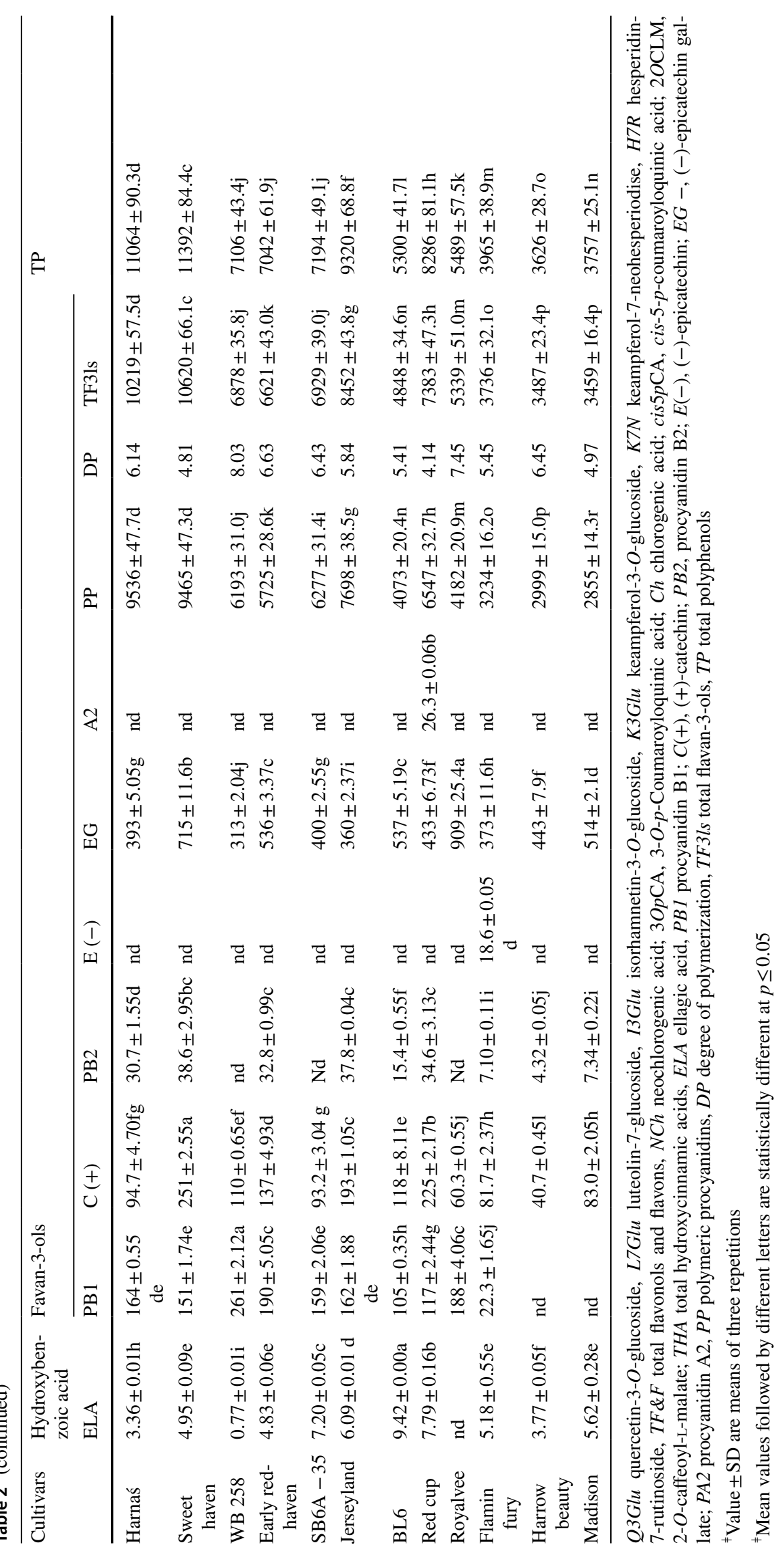


cultivars), and cis-5-p-coumaroyloquinic acid (from 21.93 to $190.80 \mathrm{mg} / 100 \mathrm{~g} \mathrm{dm}$ depending on the cultivar, except ten cultivars).

Generally, the group of hydroxycinnamic acids was the second main fraction of polyphenols in peach kernels, after flavan-3-ols. Their total content in the tested kernels ranged from $130.94 \mathrm{mg}$ in 'Harrow beauty' to $2275.95 \mathrm{mg} / 100 \mathrm{~g}$ in 'Spring time' (average $579.71 \mathrm{mg} / 100 \mathrm{~g} \mathrm{dm}$ ). The high content of hydroxycinnamic acids in peach kernels is very important considering their bioactivity, because this fraction has been identified as the main group of phenolic compounds responsible for the in vitro anti-cancer (breast, colon and liver), antioxidant and anti-aging activities [26].

Among hydroxybenzonic acids, only ellagic acid was detected, but in trace amounts. Its content ranged from $9.42 \mathrm{mg}$ (in 'BL6') to $0.77 \mathrm{mg}$ (in 'WB 258') per $100 \mathrm{~g}$ $\mathrm{dm}$. Compared to the ellagitannin-rich fruits like raspberries (average $233.50 \mathrm{mg} / 100 \mathrm{~g} \mathrm{fw}$ ) or to pomegranates (over $10 \mathrm{~g} / 100 \mathrm{~g} \mathrm{dm}$ ), the peach kernels are poor sources of this fraction of polyphenols [20,21].

The last group of polyphenols identified in peach kernels was flavonols and flavons. Their content ranged from $1.48 \mathrm{mg} / 100 \mathrm{~g} \mathrm{dm}$ in 'Flamin fury' to $99.56 \mathrm{mg} / 100 \mathrm{~g} \mathrm{dm}$ in 'Harbringer', while they were not detected in kernels isolated from 'WB 258'. In most of the tested kernels, the final content of flavonols was affected by isorhamnetin-3-O-glucoside and keampferol-3-O-glucoside, but these two compounds were not detected in all analyzed peach cultivars. The content of isorhamnetin derivatives ranged from $0.53 \mathrm{mg}$ of 'Harnaś' to $66.67 \mathrm{mg}$ of 'Spring time' per $100 \mathrm{~g} \mathrm{dm}$. In the case of keampferol-3-O-glucoside, its content was from $1.98 \mathrm{mg}$ ('Harrow beauty') to $63.14 \mathrm{mg} / 100 \mathrm{~g} \mathrm{dm}$ ('Harbringer'). The other compounds identified in peach kernels were found in trace amounts with average contents as follows: quercetin-3-O-glucoside $2.87 \mathrm{mg} / 100 \mathrm{~g} \mathrm{dm}$ (identified only in two cultivars); luteolin-7-glucoside $1.61 \mathrm{mg} / 100 \mathrm{~g} \mathrm{dm}$ (present in 18 cultivars); keampferol-7-neohesperidoside $0.62 \mathrm{mg} / 100 \mathrm{~g}$ $\mathrm{dm}$ (determined in 7 cultivars), and hesperidin-7-rutinoside $0.55 \mathrm{mg} / 100 \mathrm{~g} \mathrm{dm}$ (present in 11 cultivars) (Table 2). Senica et al. [23] reported a similar content of quercetin-3-O-glucoside in kernels of apricots $(0.22 \mathrm{mg} / 100 \mathrm{~g})$, additionally, they also found other derivatives of quercetin such as galactoside, glycoside, rutinoside and also derivatives of naringenin. In contrast, according to Mokrani et al. [18], peach fruits show a much higher content of flavonols than kernels (from 920 to $3120 \mathrm{mg} / 100 \mathrm{~g} \mathrm{dm}$ depending on cultivar). Therefore, it can be concluded that flavonols accumulate mainly in edible parts of peach fruits, while only in trace amounts in kernels.

\section{Identification and quantification of tetraterpenoids in kernels of peach stones}

Besides the polyphenols, also tetraterpenoids were identified in the peach kernels (Table 1). The tetraterpenoids, likewise polyphenols, are classified as both preventive and intervention antioxidants, and are characterized by valuable biological properties the best documented of which is their provitamin activity [27]. In our study, six carotenoids were determined in the analyzed kernels using LC-MS/ QTof, along with their retention times $\left(t_{\mathrm{R}}\right)$, UV-Vis spectral profiles at 200-800 $\mathrm{nm}$ and a comparison with standard. They were: lutein with $[\mathrm{M}+\mathrm{H}]^{+}$ion at $\mathrm{m} / \mathrm{z}=568$ and on the resulting product ions at $\mathrm{m} / \mathrm{z}=551$; zeaxanthin with pseudomolecular ions at $\mathrm{m} / \mathrm{z}=569$ and also $\beta$-carotene with $[\mathrm{M}+\mathrm{H}]^{+}$ion at $m / z=437$ that fragmented at $\mathrm{m} / \mathrm{z}=445$. In addition, $\beta$-cryptoxanthin $\left([\mathrm{M}+\mathrm{H}]^{+}\right.$at $\left.\mathrm{m} / \mathrm{z}=553, R_{t}=7.41\right)$ and its two monoesters, including: $\beta$-cryptoxanthin-myristate $\left([\mathrm{M}+\mathrm{H}]^{+}\right.$at $\left.\mathrm{m} / \mathrm{z}=763, R_{t}=12.65\right)$ and $\beta$-cryptoxanthinpalmitate $\left([\mathrm{M}+\mathrm{H}]^{+}\right.$at $\left.\mathrm{m} / \mathrm{z}=763, R_{t}=12.85\right)$, were detected in peach kernels. No peach cultivars have been analyzed from this perspective until now. But the carotenoid profile identified in the analyzed kernels is in agreement with the findings reported by Giuffrida et al. [28], who determined the same compounds in peach extracts and different peach products.

Figure 1 presents results of determinations of tetraterpenoids content in kernels of the studied cultivars of peaches. The total content of carotenoids differed significantly among the analyzed kernels and ranged from $1.53 \mathrm{mg}$ in 'Jerseyland' to $101.71 \mathrm{mg}$ in 'Harbriner' per $100 \mathrm{~g} \mathrm{dm}$, while no carotenoids were detected in two analyzed cultivars ('BL6' and 'Red cup'). In addition, the total carotenoid profile (six identified compounds) was determined in kernels of only one tested cultivar ('Kijowska wczesna').

The most commonly identified compound in kernels of different peach cultivars was zeaxanthin and its content ranged from $27.38 \mathrm{mg}$ in 'Early redhaven' to $1.44 \mathrm{mg} / 100 \mathrm{~g}$ $\mathrm{dm}$ in 'Jerseyland'. Also $\beta$-carotene was determined in 15 out of the 20 studied cultivars, with the average content of $8.42 \mathrm{mg} / 100 \mathrm{~g} \mathrm{dm}$ of kernels. Other four compounds were present in trace average amounts, i.e., lutein $(0.34 \mathrm{mg} / 100 \mathrm{~g}$ $\mathrm{dm}), \beta$-cryptoxanthin $(1.01 \mathrm{mg} / 100 \mathrm{~g} \mathrm{dm}), \beta$-cryptoxanthinmyristate $(0.84 \mathrm{mg} / 100 \mathrm{~g} \mathrm{dm})$, and $\beta$-cryptoxanthinpalmitate $(0.39 \mathrm{mg} / 100 \mathrm{~g} \mathrm{dm})$.

Cao et al. [29], who analyzed peels and flash of two peach cultivars, showed that the carotenoid profiles in pulp fruit were similar to those in peels, however, the content of these compounds in these two morphological parts was totally different. It confirms our observation, which suggests that the carotenoid profile in kernels is similar to that in fruit, but the content is much lower. Probably, the low content of tetraterpenoids in kernels is caused by a degradative enzyme 


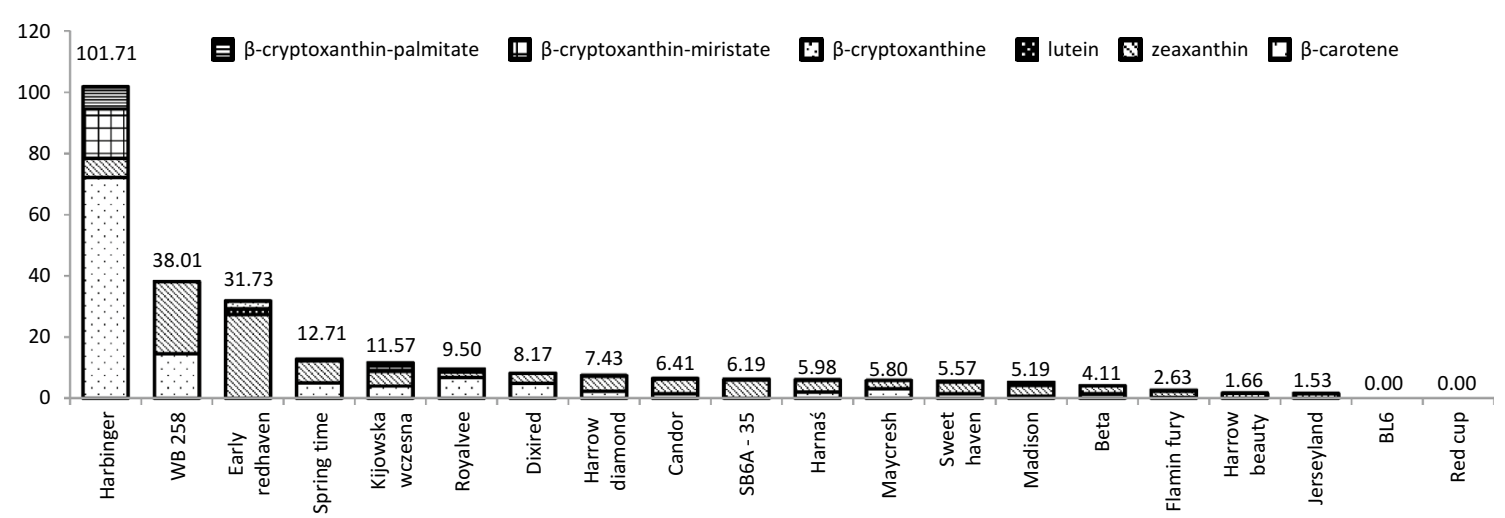

Fig. 1 Content of carotenoids $(\mathrm{mg} / 100 \mathrm{~g} \mathrm{dm})$ in the kernels separated from different cultivars of peach fruit

involved in carotenoid metabolism [30]. In peach fruit it is PpCCD4 which is associated with the white color by transforming carotenoids into colorless compounds [29].

\section{Content of cyanogenic glycoside in kernels of different peach cultivars}

Figure 2 presents results of quantification of the cyanogenic glycoside content in peach kernels analyzed in this study. In the majority of the analyzed kernels, the predominating cyanogenic glycoside was prunasin. Its highest content was determined in 'WB 258' (178.3 mg/100 g dm) and the lowest one $(15.8 \mathrm{mg} / 100 \mathrm{~g} \mathrm{dm})$ in 'Flamin fury', while no prunasin was detected in the early-maturing cultivars - 'Harbrnger' and 'Spring time'. In turn, the content of amygdalin ranged from $154.4 \mathrm{mg}$ in 'Kijowska wczesna' to $0.7 \mathrm{mg} /$ of 'Harrow diamond' and 'Maycresh' in $100 \mathrm{~g}$ $\mathrm{dm}$, while it was not detected in 'WB 258'. Bolarinwa et al. [31] determined a much higher content of amygdalin in kernels of fruits of the Rosaceae family, including: apricot $(1437 \mathrm{mg} / 100 \mathrm{~g})$, peach $(681 \mathrm{mg} / 100 \mathrm{~g})$, sweet cherries (389 mg/100 g), apples (296 mg/100 g), and purple plum
$(216 \mathrm{mg} / 100 \mathrm{~g})$. Also Yildirim and Askin [32] determined average contents of amygdalin at $861 \mathrm{mg} / 100 \mathrm{~g}$ of fm and $5559 \mathrm{mg} / 100 \mathrm{~g}$ in kernels of sweet and bitter cultivars of apricot, respectively.

Our study showed prunasin to be the predominant cyanogenic glycoside in kernels of different peach cultivars (except from the early-maturing cultivars: 'Kijowska wczesna', 'Harbringer' and 'Spring time'). Senica et al. [23] made a similar observed in kernels of apricot and sweet cherry. Prunasin is a derivative of amygdalin, which in terms of chemical structure differs in one sugar molecule less. It is formed during the hydrolysis of amygdalin, under the influence of enzymes contained in the raw material, especially $\beta$-glucosidase. As a result of mechanical damage of raw materials, the enzymes are released from the lysosomes and start successive degradation of amygdalin which lasts until thermal inactivation of enzymes at high temperature. The sudden arrest of the reaction during the extraction may explain the low content of non-hydrolyzed amygdalin in the tested peach kernels. Differences in the enzymatic activity of the raw material may also be the reason of differences within the examined cultivars [23, 32].
Fig. 2 Content of cyanogenic glycoside $(\mathrm{mg} / 100 \mathrm{~g} \mathrm{dm})$ in the kernels separated from different cultivars of peach fruit

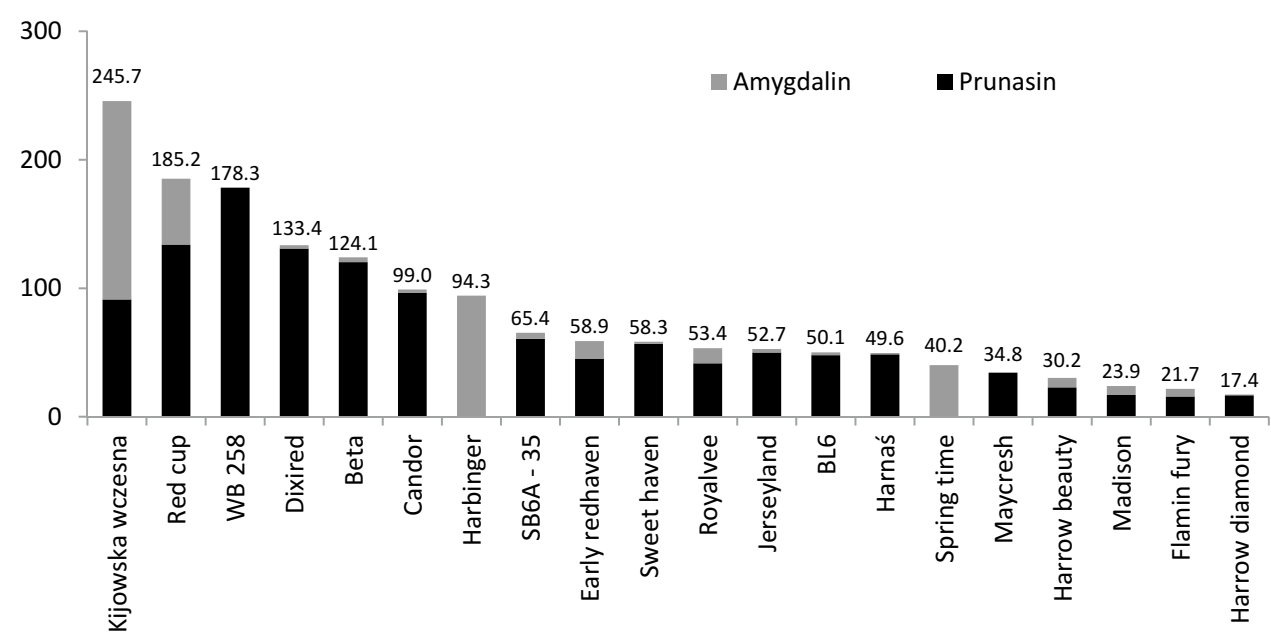




\section{Antioxidative activity of kernels of peach stones}

The antioxidative activity of the analyzed peach kernels was evaluated using two different in vitro assays: radical scavenging capacity assay (ABTS) and oxygen radical absorbance capacity (ORAC) (Table 3). Significant differences were observed among the cultivars with reference to the antioxidative activity, but the kernel extracts displayed similar correlations when assayed with both the methods applied Pearson correlation (PC) coefficient $=0.966$ (Table 4). The antioxidative activity of the peach kernels evaluated with the ABTS ranged from $2.19 \mathrm{mmol}$ TE ('Royalvee') to $27.20 \mathrm{mmol} \mathrm{TE} / 100 \mathrm{~g} \mathrm{dm}$ ('Kijowska wczesna'), and that analyzed by the ORAC method ranged from $8.03 \mathrm{mmol} \mathrm{TE} / \mathrm{in}$ 'Royalvee' to $69.59 \mathrm{mmol} \mathrm{TE} / 100 \mathrm{~g} \mathrm{dm}$ in 'Harbringer'. The highest antioxidative activity was found in kernels of the early-maturing cultivars of peach: 'Harbringer', 'Kijowska wczesna' and 'Spring time', while the lowest was displayed by late-maturing cultivars 'Royalvee', 'Flamin fury' and 'Harrow beauty'.

It was observed that not only the total content of polyphenols $(\mathrm{PC}=0.557$ and 0.476 for ABTS and ORAC, respectively) but also the type of phenolic compounds played a very important role in the antioxidative activity of peach kernels. The obtained results suggest that the antioxidative activity of peach kernels is the most related to the presence of total flavonols and flavons $(\mathrm{PC}=0.748$ and 0.818 for ABTS and ORAC, respectively), then to hydroxycinnamic acid ( $\mathrm{PC}=0.636$ and 0.619 for $\mathrm{ABTS}$ and ORAC, respectively), and can also be ascribed to polymeric procyanidins ( $\mathrm{PC}=0.491$ and 0.409 for ABTS and ORAC, respectively). In turn, negative correlations were found between the results of both total antioxidative assays and total hydroxybenzoic acid and flavan-3-ol monomers and dimers content. It was earlier confirmed by Bandoniene and Murkovic [33], who showed that the antioxidative activity in apples was to the greatest extent influenced by oligomers of procyanidins. In turn, Kirakosyan et al. [34] showed that the contents of kaempferol, quercetin and isorhamnetin derivatives determined the antioxidative activity of cherry fruit. They showed also that mutual interactions between polyphenolic compounds can cause both an increase and a decrease in the total antioxidative activity of the raw material. Moreover, Mokrani et al. [18] demonstrated that polyphenols present in all peach fruit extracts were potent anti-oxidative agents and suggested

Table 3 Enzyme of $\alpha$-amylase. $\alpha$-glucosidase, pancreatic lipase, acetylcholinesterase, butyrylcholinesterase inhibitory activities and antioxidant capacity of analyzed peach kernels

\begin{tabular}{|c|c|c|c|c|c|c|c|}
\hline \multirow[t]{2}{*}{ Cultivars } & \multicolumn{2}{|c|}{$\begin{array}{l}\text { Antioxidant activity }(\mathrm{mmol} \\
\text { trolox/100 } \mathrm{g} \mathrm{dm})\end{array}$} & \multicolumn{5}{|c|}{ Enzyme inhibition $\mathrm{IC}_{50}$ (mg of dried seeds) } \\
\hline & ORAC & ABTS & $\alpha$-Amylase & $\alpha$-Glucosidase & Pancreatic lipase & AChe & BChe \\
\hline Harbinger & $69.59 \pm 3.02 \mathrm{a}$ & $26.10 \pm 0.48 \mathrm{a}$ & $3.65 \pm 0.09 \mathrm{k}$ & $2.54 \pm 0.00 f$ & $0.49 \pm 0.01 \mathrm{~m}$ & $2.25 \pm 0.78 \mathrm{f}$ & $0.92 \pm 0.19 \mathrm{j}$ \\
\hline Kijowska wczesna & $58.66 \pm 0.99 b$ & $27.20 \pm 1.07 \mathrm{a}$ & $1.94 \pm 0.011$ & $1.00 \pm 0.07 i$ & $0.49 \pm 0.00 \mathrm{~m}$ & $0.67 \pm 0.13 h$ & $0.93 \pm 0.02 \mathrm{j}$ \\
\hline Spring time & $46.34 \pm 0.77 \mathrm{c}$ & $21.68 \pm 1.28 b$ & $3.60 \pm 0.01 \mathrm{k}$ & $1.79 \pm 0.17 \mathrm{gh}$ & $0.10 \pm 0.03 \mathrm{o}$ & $1.02 \pm 0.44 \mathrm{~h}$ & $1.02 \pm 0.15 \mathrm{i}$ \\
\hline Beta & $13.18 \pm 2.43 \mathrm{hi}$ & $6.25 \pm 0.18 \mathrm{j}$ & $7.53 \pm 0.32 \mathrm{~h}$ & $7.76 \pm 0.56 \mathrm{c}$ & $2.12 \pm 0.04 \mathrm{f}$ & $5.85 \pm 0.76 \mathrm{c}$ & $3.84 \pm 0.64 \mathrm{f}$ \\
\hline Maycresh & $20.52 \pm 0.44 \mathrm{f}$ & $8.69 \pm 0.19 \mathrm{~g}$ & $16.01 \pm 0.02 b$ & $2.14 \pm 0.00 \mathrm{fg}$ & $2.23 \pm 0.00 \mathrm{e}$ & $2.84 \pm 0.36 \mathrm{ef}$ & $4.81 \pm 0.30 \mathrm{e}$ \\
\hline Harrow diamond & $21.81 \pm 1.15 \mathrm{f}$ & $7.83 \pm 0.21 \mathrm{~h}$ & $13.39 \pm 0.58 \mathrm{~d}$ & $4.20 \pm 0.31 \mathrm{e}$ & $1.93 \pm 0.19 \mathrm{~g}$ & $2.77 \pm 0.91 \mathrm{ef}$ & $3.93 \pm 0.54 \mathrm{f}$ \\
\hline Dixired & $22.98 \pm 0.54 f$ & $8.82 \pm 0.25 \mathrm{~g}$ & $8.84 \pm 0.23 \mathrm{~g}$ & $5.11 \pm 1.10 \mathrm{~d}$ & $1.37 \pm 0.01 \mathrm{k}$ & $1.74 \pm 0.32 \mathrm{~g}$ & $4.13 \pm 0.16 f$ \\
\hline Candor & $23.07 \pm 0.69 \mathrm{f}$ & $10.31 \pm 0.32 \mathrm{f}$ & $6.01 \pm 0.01 \mathrm{i}$ & $1.63 \pm 0.49 \mathrm{ghi}$ & $1.52 \pm 0.00 \mathrm{j}$ & $3.14 \pm 0.23 \mathrm{e}$ & $3.90 \pm 0.44 f$ \\
\hline Harnaś & $27.17 \pm 1.43 \mathrm{e}$ & $11.89 \pm 0.35 \mathrm{e}$ & $1.90 \pm 0.121$ & $1.80 \pm 0.00 \mathrm{gh}$ & $1.56 \pm 0.00 \mathrm{i}$ & $1.60 \pm 0.29 \mathrm{~g}$ & $5.05 \pm 0.74 \mathrm{de}$ \\
\hline Sweet haven & $26.47 \pm 1.55 \mathrm{e}$ & $13.62 \pm 0.37 \mathrm{~d}$ & $5.09 \pm 0.00 \mathrm{j}$ & $1.41 \pm 0.00 \mathrm{hi}$ & $1.38 \pm 0.01 \mathrm{k}$ & $18.17 \pm 1.71 \mathrm{a}$ & $3.65 \pm 0.41 \mathrm{fg}$ \\
\hline WB 258 & $38.50 \pm 1.22 \mathrm{~d}$ & $19.30 \pm 1.59 b$ & $2.17 \pm 0.041$ & $5.51 \pm 0.01 \mathrm{~d}$ & $0.43 \pm 0.01 \mathrm{n}$ & $0.96 \pm 0.18 \mathrm{~h}$ & $1.67 \pm 0.26 \mathrm{~h}$ \\
\hline Early redhaven & $13.57 \pm 0.70 \mathrm{i}$ & $4.78 \pm 0.141$ & $16.15 \pm 0.43 b$ & $5.54 \pm 0.21 \mathrm{~d}$ & $0.77 \pm 0.001$ & $1.91 \pm 0.09 \mathrm{fg}$ & $5.99 \pm 0.47 \mathrm{~d}$ \\
\hline SB6A -35 & $15.92 \pm 0.23 \mathrm{~h}$ & $5.68 \pm 0.20 \mathrm{k}$ & $14.26 \pm 0.46 \mathrm{c}$ & $11.32 \pm 0.00 \mathrm{a}$ & $1.64 \pm 0.00 \mathrm{~h}$ & $2.49 \pm 0.55 \mathrm{ef}$ & $5.52 \pm 0.32 \mathrm{~d}$ \\
\hline Jerseyland & $20.32 \pm 0.40 \mathrm{f}$ & $10.41 \pm 0.30 \mathrm{f}$ & $7.52 \pm 0.00 \mathrm{~h}$ & $2.27 \pm 0.00 \mathrm{fg}$ & $1.85 \pm 0.03 \mathrm{~g}$ & $5.51 \pm 0.17 \mathrm{c}$ & $4.33 \pm 0.74 \mathrm{ef}$ \\
\hline BL6 & $16.58 \pm 0.37 \mathrm{~g}$ & $6.98 \pm 0.47 i$ & $10.18 \pm 0.23 f$ & $5.54 \pm 0.75 \mathrm{~d}$ & $1.89 \pm 0.07 \mathrm{~g}$ & $5.06 \pm 0.80 \mathrm{c}$ & $6.78 \pm 0.54 c$ \\
\hline Red cup & $27.54 \pm 1.14 \mathrm{e}$ & $15.96 \pm 0.17 \mathrm{c}$ & $5.82 \pm 0.04 \mathrm{i}$ & $1.41 \pm 0.00 \mathrm{hi}$ & $1.75 \pm 0.02 \mathrm{~h}$ & $5.06 \pm 0.80 \mathrm{c}$ & $3.45 \pm 0.17 \mathrm{~g}$ \\
\hline Royalvee & $8.03 \pm 0.141$ & $2.19 \pm 0.37 \mathrm{o}$ & $15.84 \pm 1.58 b$ & $4.97 \pm 0.58 \mathrm{~d}$ & $2.76 \pm 0.01 \mathrm{~d}$ & $2.83 \pm 0.80 \mathrm{ef}$ & $4.69 \pm 0.04 \mathrm{e}$ \\
\hline Flamin fury & $8.47 \pm 0.19 \mathrm{k}$ & $4.24 \pm 0.08 \mathrm{~m}$ & $19.36 \pm 0.11 \mathrm{a}$ & $11.58 \pm 0.21 \mathrm{a}$ & $3.83 \pm 0.02 \mathrm{c}$ & $3.37 \pm 0.29 \mathrm{e}$ & $11.31 \pm 0.45 \mathrm{a}$ \\
\hline Harrow beauty & $10.39 \pm 0.33 \mathrm{j}$ & $3.84 \pm 0.36 n$ & $10.31 \pm 0.16 f$ & $10.19 \pm 0.00 \mathrm{~b}$ & $4.92 \pm 0.02 b$ & $7.63 \pm 0.56 b$ & $7.54 \pm 0.01 \mathrm{~b}$ \\
\hline Madison & $14.33 \pm 0.61 \mathrm{~h}$ & $4.58 \pm 0.161$ & $12.39 \pm 0.21 \mathrm{e}$ & $7.13 \pm 0.27 c$ & $5.29 \pm 0.02 \mathrm{a}$ & $5.57 \pm 0.26 \mathrm{c}$ & $7.82 \pm 0.00 \mathrm{~b}$ \\
\hline
\end{tabular}

${ }^{\ddagger}$ Value \pm SD are means of three repetitions

${ }^{\ddagger}$ Mean values followed by different letters are statistically different at $p \leq 0.05$ 
Table 4 Pearson correlation between bioactive compounds and pro-health properties of analyzed peach kernels

\begin{tabular}{|c|c|c|c|c|c|c|c|}
\hline \multirow[t]{2}{*}{ Pearson correlation } & \multicolumn{2}{|c|}{$\begin{array}{l}\text { Antioxidant } \\
\text { activity }\end{array}$} & \multicolumn{5}{|c|}{ Enzyme inhibition $\mathrm{IC}_{50}$} \\
\hline & ORAC & ABTS & $\alpha$-Amylase & $\alpha$-Glucosidase & Pancreatic lipase & AChe & BChe \\
\hline THA & 0.619 & 0.636 & 0.524 & 0.529 & 0.509 & 0.054 & 0.547 \\
\hline THB & -0.573 & -0.509 & -0.437 & -0.199 & -0.232 & -0.257 & -0.434 \\
\hline $\mathrm{TF} \& \mathrm{~F}$ & 0.818 & 0.748 & 0.459 & 0.321 & 0.462 & 0.244 & 0.583 \\
\hline PP & 0.409 & 0.491 & 0.468 & 0.670 & 0.621 & 0.025 & 0.626 \\
\hline $\mathrm{m} \& \mathrm{~d}$ F31s & -0.160 & -0.111 & 0.027 & 0.280 & 0.125 & -0.420 & 0.099 \\
\hline ТP & 0.476 & 0.557 & 0.524 & 0.727 & 0.667 & 0.001 & 0.678 \\
\hline $\mathrm{TC}$ & 0.666 & 0.521 & 0.251 & 0.157 & 0.393 & 0.238 & 0.433 \\
\hline TGC & 0.515 & 0.609 & 0.577 & 0.318 & 0.489 & 0.222 & 0.585 \\
\hline BChe & 0.782 & 0.800 & 0.716 & 0.680 & 0.761 & 0.122 & \\
\hline AChe & 0.251 & 0.184 & -0.082 & -0.062 & 0.240 & & \\
\hline Pancreatic lipase & 0.653 & 0.682 & 0.505 & 0.556 & & & \\
\hline$\alpha$-Glucosidase & 0.541 & 0.598 & 0.582 & & & & \\
\hline$\alpha$-Amylase & 0.693 & 0.770 & & & & & \\
\hline ABTS & 0.966 & & & & & & \\
\hline
\end{tabular}

$T H A$ total hydroxycinnamic acids, $T F$ total flavonols and flavons, $T H B$ total hydroxybenzonic acid, $P P$ polymeric procyanidins, $m \& d T F 3 l s$ total monomer and dimmers flavan-3-ols, $T P$ total polyphenols, $T C$ total carotenoids, $T G C$ total ceanogenic glycoside that cultivar might have a significant influence on the antioxidative activity of peach fruits.

Apart from the polyphenols, positive correlations were also found between the antioxidative activity and content of carotenoids ( $\mathrm{PC}=0.521$ and 0.666 for ABTS and ORAC, respectively) and between antioxidative activity and cyanogenic glycoside $(\mathrm{PC}=0.609$ and 0.515 for ABTS and ORAC, respectively). Many researchers indicate that the structure of conjugated double bonds in the polyene backbone influences the high antioxidative activity of carotenoids [18]. In the case of cyanogenic glucosides, recently, great attention has been paid to the potential beneficial effects of amygdalin in the prevention and even treatment of cancer. Although cyanogenic glucosides are claimed to be toxic in large amounts, it is assumed that in lower doses they may have pro-health properties. They have been found to exhibit high antimicrobial, antioxidant, anti-inflammatory and analgesic activities, and also to inhibit the development of human breast, intestine and liver cancer cells which was confirmed by in vitro analyses [5, 23, 31, 32].

\section{Inhibitory activities of peach kernels toward digestive enzymes}

In this work, the inhibition of $\alpha$-glucosidase, $\alpha$-amylase, and lipase by kernel extracts from 20 cultivars of peach were investigated using $p$-nitrophenyl- $\alpha$-D-glucopyranoside, potato starch, and $p$-nitrophenyl acetate as substrates, respectively. All of the kernel extracts were tested for their inhibitory effect at different concentrations, which enabled calculating the $\mathrm{IC}_{50}$ values that are presented in Table 3.

Pancreatic lipase is a key enzyme in dietary fat absorption, responsible for the hydrolysis of $50-70 \%$ of dietary triglycerides into 2-monoacylglycerides and free fatty acids, which can then be absorbed by enterocytes. Inhibition of this enzyme is used to reduce dietary fat absorption and, therefore, the use of phytoextracts as pancreatic lipase inhibitors may represent an alternative approach for weight loss treatment [35]. Significant differences $(p<0.05)$ were observed among the kernel cultivars with reference to the inhibitory activity toward porcine pancreatic lipase type II. The inhibitory effect of the peach kernels ranged from 0.10 to $5.29 \mathrm{mg} / 100 \mathrm{dm}$. Among the 20 tested cultivars, the kernels isolated from the early-maturing peaches were the most active ('Spring time' >> 'Kijowska wczesna' and 'Harbringer'), while the kernels from the late-maturing peaches showed the highest $\mathrm{IC}_{50}$ value ('Madison', 'Harrow beauty' and 'Flamin fury'). A positive correlation was observed between the inhibitory activity toward porcine pancreatic lipase and the total content of polyphenols $(\mathrm{PC}=0.667)$. It is well known that polyphenols can bind proteins through hydrogen bonding or hydrophobic effects, leading to their complexation and precipitation. It means that extracts of different plants could potentially inhibit enzymes by aggregation. However, the mechanism by which these substances inhibit pancreatic lipase is unclear, due to the synergy between many compounds of plant extracts [36]. Our study also showed that the type of phenolic compounds played an important role in the 
inhibitory activity of peach kernels. The inhibitory activity of the peach kernels was the most related to the presence of total polymeric procyanidins $(\mathrm{PC}=0.621)$, and hydroxycinnamic acid $(\mathrm{PC}=0.509)$. Other authors showed also that the oligomeric proanthocyanidins (contained in apples or seed grapes) were effective lipase inhibitors in vitro and prevent triglyceride absorption in human and in mice models [37, 38].

The incidence of obesity is associated with the incidence of diabetes type 2 , characterized by elevated blood glucose levels. Type 2 diabetes represents $90 \%$ of all diabetes cases and is the major cause of deaths among other diet-related diseases. The insulin-independent diabetes is linked with insulin resistance which precedes or the dysfunction of $\beta$ cells that are no longer capable of synthesizing a sufficient quantity of insulin to maintain normoglycemia [39]. It was shown that polyphenols have many biological activities and constitute an important part of the human diet also in the prevention of type 2 diabetes. Their hypoglycemic effect results from their antioxidative potential involved in restoring the insulin-secreting machinery in pancreatic cells, or abilities to inhibit the activity of carbohydrate-hydrolyzing enzymes ( $\alpha$-amylase and $\alpha$-glucosidase) $[13,39,40]$. Therefore, in this study the anti- $\alpha$-amylase and $-\alpha$-glucosidase activities were measured and the results are presented as $\mathrm{IC}_{50}$ values in Table 3. Significant differences $(p<0.05)$ were found among the analyzed kernels in the inhibitory activities toward $\alpha$-amylase, and $\alpha$-glucosidase. The inhibition of $\alpha$-amylase, presented as the $\mathrm{IC}_{50}$ values, ranged from 1.90 to $19.36 \mathrm{mg} \mathrm{dm}$ of kernels $/ \mathrm{mL}$, while of $\alpha$-glucosidase was from 1.00 to $11.58 \mathrm{mg} / \mathrm{mL}$. As in the case of lipase inhibition, the strongest inhibition against the carbohydratehydrolyzing enzymes was displayed be the kernels isolated from the early-maturing 'Kijowska wczesna', while the weakest one by the kernels from the late-maturing ('Flamin fury'). The inhibitory effect toward $\alpha$-amylase and $\alpha$-glucosidase stimulated the most the content of polyphenols ( $\mathrm{PC}=0.524$ and 0.727 , respectively), but a highly positive correlation was also observed with contents of polymeric procyanidins $(\mathrm{PC}=0.468$ and 0.670 , respectively), hydroxycinnamic acid $(\mathrm{PC}=0.524$ and 0.529 , respectively). Other study [40] suggested also that procyanidins are effective inhibitors of $\alpha$-amylase activity as they form enzyme-tannin complexes, which prevents the enzyme from interacting with starch. In addition, these authors showed that flavonols can interact with hydroxycinnamic acids increasing the inhibition of $\alpha$-glucosidase [40].

Despite the promising results obtained in this study, further research is required to confirm that plant components can inhibit lipase, $\alpha$-amylase and $\alpha$-glucosidase in vivo, prevent fat intake and carbohydrates absorption and that they do so at levels achievable from normal diets.

\section{Inhibitory activities of peach kernels toward cholinesterase}

Alzheimer's disease (AD) is an age-related neurodegenerative disorder characterized by progressive cognitive dysfunction leading to dementia. Treatment of AD symptoms relies primarily on cholinesterase inhibition by ensuring adequate levels of acetylcholine ( $\mathrm{ACh}$ ) at neurotransmission sites. In the brain, there are two main forms of cholinesterases-acetylcholinesterase (AChE) and butyrylcholinesterase (BuChE) [16]. AChE is found in all excitable tissues (nerve, muscle or in erythrocytes), while BuChE is present in the body, including the nervous system, plasma and liver [41]. Inhibiting the two enzymes was the best established approach to treat $\mathrm{AD}$ currently, so the inhibition effect of $\mathrm{AChE}$ and BuChE from peach kernels was determined (Table 3).

Significant differences $(p<0.05)$ were found among the analyzed kernels, in the inhibitory potential against AChE and $\mathrm{BuChE}$. The inhibition of $\mathrm{AChE}$, presented as the $\mathrm{IC}_{50}$ value, ranged from 0.67 in the case of kernels from 'Kijowska wczesna' to $18.17 \mathrm{mg} \mathrm{dm}$ of 'Sweet haven' kernels $/ \mathrm{mL}$. In turn, the inhibition of BuChE was from 0.92 to $11.31 \mathrm{mg} / \mathrm{mL}$ and as in the case of inhibition of lipase, $\alpha$-amylase and $\alpha$-glucosidase the strongest inhibition against the enzymes was shown by the kernels isolated from the early-maturing, while the weakest ones by the kernels from the late-maturing cultivars. The inhibiting potential of the analyzed kernels against $\mathrm{AChE}$ was similar to that measured by Zengin et al. [41] in medicinal plants (Hedysarum varium, Onobrychis hypargyrea and Vicia truncatula), but poorer than in plants of the Lamiaceae family (menthe, sweet balm, origanum) [42]. In turn, peach kernels showed a higher inhibiting potential toward $\mathrm{BuChE}$, compared to the above-mentioned medicinal plants [41].

In addition, positive correlations were determined between the inhibitory effect of kernels toward $\mathrm{BuChE}$ and content of total polyphenols ( $\mathrm{PC}=0.678)$, total carotenoids $(\mathrm{PC}=0.433)$ and also total cyanogenic glycosides $(P C=0.585)$. Such a correlation was not detected in the case of AChE. In turn, in the case of both analytical methods, a positive correlation was observed between antioxidative activity and inhibitory activities of peach kernels (PC $(\mathrm{ORAC} / \mathrm{BuChE})=0.782 ; \mathrm{PC}(\mathrm{ABTS} / \mathrm{BuChE})=0.800 ; \mathrm{PC}$ $(\mathrm{ORAC} / \mathrm{AChE})=0.251 ; \mathrm{PC}(\mathrm{ABTS} / \mathrm{AChE})=0.184)$. It was confirmed by other authors, who showed that free radical and oxidative stress is a major reason of degeneration of cells and of the earliest events in the pathogenesis of $\mathrm{AD}[16$, 42]. Therefore, the antioxidative activity of plants could be 
considered beneficial both in the prevention and treatment of AD.

The analysis of the cholinesterase-inhibiting activities of peach kernels was a very important element of this study, because it showed that the compounds contained in the analyzed kernels could be a healthy alternative to strongly addictive drugs currently dedicated to people with senile dementia problems.

\section{Conclusion}

The presented study provides important insights on the health properties of kernels isolated from the peach of Prunus persica related to their polyphenol, carotenoid and cyanogenic glycoside profiles, antioxidant capacity and in vitro potential to inhibit enzymes relevant to hyperglycemia, obesity ( $\alpha$-amylase, $\alpha$-glucosidase, pancreatic lipase) and Alzheimer's disease (AChE and BuChE) management. Such results have not been published so far.

It has been shown that peach kernels were characterized by a similar profile of bioactive compounds as other morphological parts of peach fruit, however, the content of some of these compounds was completely different. Peach kernels had definitely higher contents of polymeric procyanidins and phenolic acids, compared to fruits, in turn the analyzed kernels had few times lower concentrations of carotenoids, flavonols and flavons. The peach kernels were also tested for the first time ever for their health properties. A high antioxidative potential of the tested raw material was demonstrated, but also its ability to inhibit enzymes linked to obesity, type 2 diabetes and Alzheimer's disease. It was indicated that the compounds contained in peach kernels were characterized by several times higher health-promoting activity than that determined in fruits or vegetables. Our study showed also that the health-promoting properties of peach kernels were stimulated mainly by polymeric procyanidins, hydroxycinnamic acids, carotenoids and cyanogenic glycosides. In addition, the analysis of the obtained results enabled indicating differences between particular cultivars of peach kernels. It has been shown that the peach kernels isolated from earlymaturing varieties as 'Kijowska Wczesna', 'Harbringer', 'Spring Time', 'Dixired', 'Red cup', 'WB 258', and 'Early Redhaven' were characterized by a higher content of polyphenolic compounds, carotenoids, antioxidative capacity and also inhibitory potential against $\alpha$-glucosidase, $\alpha$-amylase, acetycholinesterase, and butyrylcholinesterase than the kernels from late-maturing cultivars.

Generally, peach kernels are an attractive waste material, containing many bioactive compounds with a high prohealth potential. Despite varietal diversity, they can be a valuable source of polyphenols used by the pharmaceutical industry for the production of dietary supplements to support the prevention and treatment of chronic non-communicable diseases. However, due to the many controversies related to the toxicity of amygdalin and prunasin, further research should be carried out to confirm or exclude their healthpromoting properties, and thus the possibility of using peach kernels as a source of bioactive compounds.

Acknowledgements This work was supported by the Foundation for Polish Science (FNP). Publication supported by Wroclaw Centre of Biotechnology, programme The Leading National Research Centre (KNOW) for years 2014-2018 and purpose subsidy 2017 (MNiSW) for The Faculty of Biotechnology and Food Sciences, Wrocław University of Environmental and Life Science.

\section{Compliance with ethical standards}

Conflict of interest The authors declare that there is no conflict of interest.

Compliance with ethics requirements The research do not include any human subjects and animal experiments.

Open Access This article is distributed under the terms of the Creative Commons Attribution 4.0 International License (http://creativeco mmons.org/licenses/by/4.0/), which permits unrestricted use, distribution, and reproduction in any medium, provided you give appropriate credit to the original author(s) and the source, provide a link to the Creative Commons license, and indicate if changes were made.

\section{References}

1. GUS (2017) Wstępny szacunek głównych ziemiopłodów rolnych i ogrodniczych w 2017 roku. Główny Urząd Statystyczny. http:// stat.gov.pl/obszary-tematyczne/rolnictwo-lesnictwo/. Accessed 28 July 2007

2. Kowalczyk R, Piwnicki Ł (2007) Pestki owoców jako cenny surowiec wtórny przemysłu spożywczego. Postępy Tech Przetwórstwa Spożywczego 17/31(2):62-66

3. Kaynak B, Topal H, Atimtay AT (2005) Peach and apricot stone combustion in a bubbling fluidized bed. FPT 86(11):1175-1193

4. Dardick CD, Callahan AM, Chiozzotto R, Schaffer RJ, Piagnani MC, Scorza R (2010) Stone formation in peach fruit exhibits spatial coordination of the lignin and flavonoid pathways and similarity to Arabidopsis Dehiscence. BMC Biol 8(13):1

5. Bak I et al (2010) Isolation and analysis of bioactive constituents of sour cherry (Prunus cerasus) seed kernel: an emerging functional food. J Med Food 13(4):905-910

6. Zhu X, Li F, Yang X, Zhao L (2011) CN102100765 (A) - processing technique of peach kernels. https://patents.google.com/paten t/CN102100765A/en?oq=CN102100765+(A). Accessed 22 June 2011

7. Xu J, Yu M, Ma R, Shen Z (2013) CN102919972 (A) - portable labor-saving shell cracking and seed taking device for peach kernels. https://patents.google.com/patent/CN102919972A/en\#cited By. Accessed 13 Feb 2013

8. Chang SK, Alasalvar C, Shahidi F (2016) Review of dried fruits: phytochemicals, antioxidant efficacies, and health benefits. J Funct Foods 21:113-132

9. Wojdyło A, Nowicka P, Laskowski P, Oszmiański J (2014) Evaluation of sour cherry (Prunus cerasus L.) fruits for their polyphenol 
content, antioxidant properties and nutritional components. J Agric Food Chem 62(51):12332-12345

10. Kennedy JA, Jones GP (2001) Analysis of proanthocyanidin cleavage products following acid-catalysis in the presence of excess phloroglucinol. J Agr Food Chem 49:1740-1746

11. Kolniak-Ostek J (2016) Content of bioactive compounds and antioxidant capacity in skin tissues of pear. J Funct Foods 23:40-51

12. Nowicka P, Wojdyło A, Samoticha J (2016) Evaluation of phytochemicals, antioxidant capacity, and antidiabetic activity of novel smoothies from selected Prunus fruits. J Funct Foods 25:397-407

13. Podsędek A, Majewska I, Redzynia M, Sosnowska D, Koziołkiewicz M (2014) In vitro inhibitory effect on digestive enzymes and antioxidant potential of commonly consumed fruits. J Agr Food Chem 62(20):4610-4617

14. Ou B, Huang D, Hampsch-Woodill M, Flanagan JA, Deemer EK (2002) Analysis of antioxidant activities of common vegetables employing oxygen radical absorbance capacity (ORAC) and ferric reducing antioxidant power (FRAP) assay: a comparative study. $\mathbf{J}$ Agric Food Chem 50:3122-3128

15. Re R, Pellegrini N, Proteggente A, Pannala A, Yang M, RiceEvans C (1999) Antioxidant activity applying an improved ABTS radical cationdecolorization assay. Free Radic Bio Med 26(9/10):1231-1237

16. Jin H, Nguyen T, Go ML (2014) Acetylcholinesterase and butyrylcholinesterase inhibitory properties of functionalized tetrahydroacridines and related analogs. Med Chem 4(10):688-696

17. Ye IH, Li NN, Lu IL, Zheng XQ, Liang Y (2014) Bulk preparation of (-)-epigallocatechin gallate-rich extract from green tea. Food Bioprod Process 92(3):275-281

18. Mokrani A et al (2016) Phenolic contents and bioactive potential of peach fruit extracts. Food Chem 202:212-220

19. Tomás-Barberán FA, Gil MI, Cremin P, Waterhouse AL, HessPierce B, Kader AA (2001) HPLC-DAD-ESIMS analysis of phenolic compounds in nectarines, peaches, and plums. J Agric Food Chem 49(10):4748-4760

20. Begon a de Ancos EM, Gonzalez Pilar Cano M (2000) Ellagic acid, vitamin $\mathrm{C}$, and total phenolic contents and radical scavenging capacity affected by freezing and frozen storage in raspberry fruit. J Agric Food Chem 48:4565-4570

21. Nuncio-Jáuregui N, Nowicka P, Munera-Picazo S, Hernández F, Carbonell-Barrachina AA, Wojdyło A (2015) Identification and quantification of major derivatives of ellagic acid and antioxidant properties of thinning and ripe Spanish pomegranates. J Funct Foods 12:354-364

22. Nüßlein B, Kreis W (2005) Purification and characterization of a cynaroside 7- $O-\beta$-D-glucosidase from Cynarae scolymi folium. Acta Hort 681:413-420

23. Senica M, Stampar F, Veberic R, Mikulic-Petkovsek M (2016) Transition of phenolics and cyanogenic glycosides from apricot and cherry fruit kernels into liqueur. Food Chem 203:483-490

24. Liu H, Cao J, Jiang W (2015) Evaluation and comparison of vitamin $\mathrm{C}$, phenolic compounds, antioxidant properties and metal chelating activity of pulp and peel from selected peach cultivars. LWT 63:1042-1048

25. Renard CC, Dupont N, Guillermin P (2007) Concentrations and characteristics of procyanidins and other phenolics in apples during fruit growth. Phytochemistry 68(8):1128-1138
26. Li F et al (2013) Antiproliferative activity of peels, pulps and stones of 61 fruits. J Funct Foods 5:1298-1309

27. Sies H, Stahl W (1995) Vitamins E and C, beta-carotene, and other carotenoids as antioxidants. AJCN 62:1315-1321

28. Giuffrida D, Torre G, Dugo P, Dugo G (2013) Determination of the carotenoid profile in peach fruits, juice and jam. Fruits 68:39-44

29. Cao S et al (2017) Accumulation of carotenoids and expression of carotenogenic genes in peach fruit. Food Chem 214:137-146

30. Nisar N, Li L, Lu S, Khin NC, Pogson BJ (2015) Carotenoid metabolism in plants. Mol Plant 8:68-82

31. Bolarinwa IF, Orfila C, Morgan MRA (2014) Amygdalin content of seeds kernels and food products commercially-available in the UK. Food Chem 152:133-193

32. Yildirim FA, Askin MA (2010) Variability of amygdalin content in seeds of sweet and bitter apricot cultivars in Turkey. Afr J Biotechnol 9(39):6522-6524

33. Bandoniene D, Murkovic M (2002) On-line HPLC-DPPH screening method for evaluation of radical scavenging phenols extracted from apples (Malus domestica L.). J Agr Food Chem 50:2482-2487

34. Kirakosyan A, Seymour EM, Urcuyo Llanes DE, Kaufman PB, Bolling SF (2009) Chemical profile and antioxidant capacities of tart cherry products. Food Chem 115:20-25

35. Sergent T, Vanderstraeten J, Winand J, Beguin P, Schneider YJ (2012) Phenolic compounds and plant extracts as potential natural anti-obesity substances. Food Chem 135:68-73

36. Birari RB, Bhutani KK (2007) Pancreatic lipase inhibitors from natural sources: unexplored potential. Drug Discov Today 12:879-889

37. Moreno DA, Ilic N, Poulev A, Brasaemleet D, Fried SK, Raskin I (2003) Inhibitory effects of grape seed extract on lipases. Nutrition 19:876-879

38. Sugiyama $\mathrm{H}$ et al (2007) Oligomeric procyanidins in apple polyphenol are main active components for inhibition of pancreatic lipase and triglyceride absorption. J Agr Food Chem 55:4604-4609

39. Devalaraja S, Jain S, Yadav H (2011) Exotic fruits as therapeutic complements for diabetes, obesity and metabolic syndrome. Food Res Int 44:1856-1865

40. Boath SA, Stewart D, McDougall JG (2012) Berry components inhibit $\alpha$-glucosidase in vitro: synergies between acarbose and polyphenols from black currant and rowanberry. Food Chem 135(3):929-936

41. Zengin G, Guler O, Aktumsek A, Ceylan R, Picot CMN, Mahomoodally MF (2015) Enzyme inhibitory properties, antioxidant activities, and phytochemical profile of three medicinal plants from Turkey. Adv Pharmacol Sci. https://doi. org/10.1155/2015/410675

42. Vladimir-Knežević S, Blažeković B, Kindl M, Vladić J, LowerNedza AD, Brantner AH (2014) Acetylcholinesterase inhibitory, antioxidant and phytochemical properties of selected medicinal plants of the Lamiaceae family. Molecules 19:767-782 